\title{
PENGGUNAAN METODE ARIMA DALAM MERAMAL PERGERAKAN INFLASI
}

\author{
Hartati \\ FMIPA Universitas Terbuka \\ e-mail: hartati@ecampus.ut.ac.id
}

\begin{abstract}
Inflation is a problem which haunts the economy of each country. Its development is which continually increasing make a drag on economic growth to a better direction. Inflation tends to occur in developing countries like Indonesia which is an agricultural country. To overcome the instability of inflation, one way to do is to predict the time series data. Methods Autoregressive Integrated Moving Average (ARIMA) has the ability to capture the necessary information about the wood as well as able to cope with the instability of inflation of inflation. This is because ARIMA is a method of forecasting time series are suited to predict the number of variables in a fast, simple, inexpensive, accurate, and only requires the data variables to be predicted.
\end{abstract}

Keywords: ARIMA, inflation, time series forecasting

\begin{abstract}
ABSTRAK
Inflasi merupakan suatu masalah yang menghantui perekonomian setiap negara. Perkembangannya yang terus-menerus mengalami peningkatan menjadi hambatan pada pertumbuhan ekonomi ke arah yang lebih baik. Perubahan laju inflasi cenderung terjadi pada negara-negara berkembang seperti halnya Indonesia yang merupakan negara agraris. Untuk menanggulangi terjadinya ketidakstabilan laju inflasi, salah satu cara yang dapat dilakukan adalah dengan meramalkan data time series. Metode Autoregressive Integrated Moving Average (ARIMA) memiliki kemampuan untuk menangkap informasi-informasi yang diperlukan mengenai laju inflasi serta mampu menanggulangi ketidakstabilan dari laju inflasi. Hal ini dikarenakan ARIMA merupakan suatu metode peramalan time series yang cocok digunakan untuk meramal sejumlah variabel secara cepat, sederhana, murah, dan akurat serta hanya membutuhkan data variabel yang akan diramal.
\end{abstract}

Kata kunci: ARIMA, inflasi, peramalan time series

Inflasi merupakan salah satu fenomena ekonomi yang selalu menarik dibahas terutama berkaitan dengan dampaknya yang luas terhadap ekonomi makro, seperti pertumbuhan ekonomi, keseimbangan eksternal, daya saing, tingkat bunga, bahkan distribusi pendapatan. Inflasi merupakan suatu masalah yang menghantui perekonomian setiap negara. Perkembangannya yang terus menerus mengalami peningkatan menjadi hambatan pada pertumbuhan ekonomi ke arah yang lebih baik. Banyak kajian yang membahas inflasi, tidak hanya cakupan regional, nasional, namun juga internasional. Inflasi cenderung terjadi pada negara-negara berkembang seperti halnya Indonesia yang merupakan negara agraris. 
Krisis ekonomi yang dipicu oleh gejolak nilai tukar rupiah telah berdampak sangat luas pada seluruh sendi perekonomian dan tatanan kehidupan. Krisis ekonomi yang telah terjadi, paling tidak dalam konteks ini, memberikan pelajaran yang berharga akan pentingnya penciptaan kestabilan moneter (kestabilan nilai rupiah) sebagai prasyarat bagi kelangsungan pembangunan ekonomi yang berkelanjutan.

Bank Indonesia selalu melakukan evaluasi apakah proyeksi inflasi ke depan masih sesuai dengan sasaran yang telah ditetapkan. Proyeksi ini dilakukan dengan sejumlah model dan sejumlah informasi yang mampu menggambarkan kondisi laju inflasi ke depan. Proyeksi laju inflasi ke depan dapat juga dilakukan dengan melakukan peramalan time series (Saluza, 2015). Beberapa penelitianpenelitian terdahulu telah melakukan peramalan dari laju inflasi, antara lain Stephani, Agus \& Suhartono (2015) meramalkan laju inflasi menggunakan pendekatan klasik dan ANFIS, sedangkan Wulandari, Setiawan \& Ahmad (2016) meramalkan laju inflasi menggunakan pendekatan ARIMA, variasi kalender, dan intervensi. Hasil penelitian mereka menunjukkan bahwa metode ARIMA cukup akurat untuk melakukan peramalan laju inflasi.

Untuk mendapatkan informasi laju inflasi semacam ini, tidak cukup hanya dengan mengandalkan informasi inflasi saat ini saja. Informasi laju inflasi dari waktu yang lampau (past) harus juga diketahui. Dari informasi-informasi inilah yang nantinya dapat membuat sebuah metode yang mampu menggambarkan bagaimana sifat-sifat laju inflasi tersebut dan informasi dari laju inflasi itu dapat terbentuk sedemikian rupa sampai dengan informasi laju inflasi pada saat ini (present). Dengan metode inilah informasi laju inflasi dapat diramalkan. Hal inilah yang disebut dengan peramalan time-series (time-series forecasting).

Peramalan time series merupakan suatu metode analisis data yang ditujukan untuk melakukan suatu estimasi maupun peramalan pada masa yang akan datang (Makridakis, Wheelwright \& McGee, 2002). Dalam peramalan time series dapat diketahui bagaimana proses suatu estimasi dan hasil dari peramalan dapat diperoleh dengan baik. Untuk itu dalam analisis ini dibutuhkan berbagai macam informasi atau data yang cukup banyak dan diamati dalam periode waktu yang relatif cukup panjang.

Untuk mendapatkan informasi-informasi yang dibutuhkan mengenai laju inflasi tersebut, metode yang digunakan adalah Autoregressive Integrated Moving Average (ARIMA). Karena ARIMA merupakan suatu statistik yang cocok digunakan untuk meramal sejumlah variabel secara cepat, sederhana, murah, dan akurat karena hanya membutuhkan data variabel yang akan diramal. Metode ARIMA menggunakan pendekatan iteratif dalam indentifikasi terhadap suatu model yang ada. Model yang dipilih diuji lagi dengan data masa lampau untuk melihat apakah model tersebut menggambarkan keadaan data secara akurat atau tidak. Peneliti-peneliti terdahulu telah banyak yang menggunakan metode ARIMA untuk melakukan peramalan, antara lain Pimpi (2013) menerapkan metode ARIMA dalam meramalkan Indeks Harga Konsumen (IHK), sedangkan Ruslan, Harahap \& Sembiring (2013) melakukan peramalan nilai ekspor di Propinsi Sumatera Utara dengan metode ARIMA Box-Jenskin. Keduanya menyatakan bahwa metode ARIMA merupakan suatu metode yang efektif dan akurat untuk melakukan peramalan data time series. Namun belum ada penelitian yang meramalkan laju inflasi di Indonesia menggunakan metode ARIMA. Oleh karena itu, penelitian ini bertujuan untuk melakukan peramalan laju inflasi di Indonesia menggunakan metode ARIMA. 


\section{METODE}

Peramalan adalah salah satu metode statistik yang berperan penting dalam pengambilan keputusan. Peramalan berfungsi untuk memperkirakan apa yang akan terjadi pada masa depan berdasarkan data masa lalu. Salah satu metode yang digunakan dalam peramalan adalah metode time series. Pendugaan masa depan dilakukan berdasarkan informasi masa lalu dari suatu variabel atau kesalahan masa lalu ini dinamakan deret berkala atau time series (Makridakis, 2002).

Metode peramalan yang biasa digunakan adalah Auto Regressive Integrated Moving Avarege (ARIMA) atau Box-Jenkins. Metode-metode Autoregresive Integrated Moving Average (ARIMA) telah dipelajari secara mendalam oleh George Box dan Gwilym Jenkins (1976), dan nama mereka sering disinonimkan dengan proses ARIMA yang diterapkan untuk analisis deret berkala, peramalan dan pengendalian. Metode auto regressive (AR) pertama kali diperkenalkan oleh Yule (1927), sedangkan metode moving average (MA) pertama kali digunakan oleh Slutsky (1937). Akan tetapi Wold (1938) menghasilkan dasar-dasar teoritis dari proses kombinasi ARMA. Wold membentuk metode ARMA yang dikembangkan pada tiga arah identifikasi efisien dan prosedur penaksiran (untuk proses AR, MA, dan ARMA campuran), perluasan dari hasil tersebut untuk mencakup deret berkala musiman dan pengembangan sederhana yang mencakup proses-proses nonstasioner (ARIMA). Menurut Makridakis, Wheelwright, dan McGee (2002) serta secara efektif telah berhasil mencapai kesepakatan mengenai informasi relevan yang diperlukan untuk memahami dan memakai metode ARIMA untuk deret berkala univariat.

Menurut Makridakis, metode ARIMA seringkali dituliskan dalam operator backshift. Notasi $B$ artinya memiliki pangkat satu, akan tetapi pangkat $B$ boleh lebih dari satu. Secara umum didefinisikan sebagai berikut:

$$
B^{k} Y_{t}=Y_{t-k}
$$

Operator backshift $B$ dapat diperluas definisinya menjadi diferensi $(1-B)$. Jika $Y_{t}$ dikalikan dengan $(1-B)$ maka akan diperoleh persamaan berikut:

$$
(1-B) Y_{t}=Y_{t}-B Y_{t}=Y_{t}-Y_{t-1}
$$

Perlu diingat bahwa $B$ bukanlah suatu bilangan, sehingga $(1-B)$ juga bukan suatu bilangan tertentu namun merupakan suatu operator.

\section{Proses Auto Regressive (AR)}

$\operatorname{AR}(p)$

$\left(1-\phi_{1} B-\phi_{2} B^{2}-\cdots-\phi_{p} B^{p}\right) Y_{t}=\delta+\varepsilon_{t}$

dimana:

$\delta=$ nilai konstan

$\phi_{p}=$ parameter auto regressive

$\varepsilon_{t}=$ nilai error pada saat $t$

\section{Proses Moving Average (MA)}

$$
\begin{aligned}
& \mathrm{MA}(q) \\
& Y_{t}=\mu+\left(1-\theta_{1} B-\theta_{2} B^{2}-\cdots-\theta_{q} B^{q}\right) \varepsilon_{t} \\
& Y_{t}=\mu+\theta_{q}(B) \varepsilon_{t}
\end{aligned}
$$


dimana:

$\mu=$ nilai konstan

$\theta_{q}=$ parameter moving average

$\varepsilon_{t}=$ nilai error pada saat $t$

\section{Proses ARIMA}

Berdasarkan AR (1) dan MA (1) akan diperoleh bentuk umum sebagai berikut:

$\operatorname{ARMA}(1,1)$

$Y_{t}=\mu+\phi_{1} Y_{t-1}+\varepsilon_{t}-\theta_{1} \varepsilon_{t-1}$

$\left(1-\phi_{1} B\right) Y_{t}=\mu+\left(1-\theta_{1} B\right) \varepsilon_{t}$

Jika nonstasioneritas ditambahkan pada campuran proses ARMA, maka model umum ARIMA $(p, d, q)$ terpenuhi. Persamaan sederhana untuk AR (1) MA (1) dan differencing $(1-B)$ atau ARIMA $(1,1,1)$ adalah sebagai berikut:

$(1-B)\left(1-\phi_{1} B\right) Y_{t}=\mu+\left(1-\theta_{1} B\right) \varepsilon_{t}$

\section{Identifikasi Model ARIMA}

- Autocorrelation Function (ACF) Proses Autoregressive (AR)

Untuk menentukan persamaan autokorelasi Autoregressive $(p)$ hal pertama yangdilakukan adalah dengan mengalikan AR (1) dengan $Y_{t-k}$ pada kedua sisi persamaan, dan untuk menyederhanakan masalah maka $\delta$ dianggap nol kemudian dicari nilai ekspektasinya sebagai berikut:

$E\left[Y_{t-k} Y_{t}\right]=E\left[\phi_{1} Y_{t-k} Y_{t-1}\right]+E\left[\phi_{2} Y_{t-k} Y_{t-2}\right]+\cdots+E\left[\phi_{p} Y_{t-k} Y_{t-p}\right]+E\left[Y_{t-k} \varepsilon_{t}\right]$

$\gamma_{k}=\phi_{1} \gamma_{k-1}+\phi_{2} \gamma_{k-2}+\cdots+\phi_{p} \gamma_{k-p}, k>0$

Dimana $E\left[Y_{t-k} Y_{t}\right]=0$ untuk $k>0$ kemudian membagi persamaan di atas dengan $\gamma_{0}$, sehingga diperoleh:

$\frac{\gamma_{k}}{\gamma_{0}}=\frac{\phi_{1} \gamma_{k-1}+\phi_{2} \gamma_{k-2}+\cdots+\phi_{p} \gamma_{k-p}}{\gamma_{0}}$

$\rho_{k}=\phi_{1} \rho_{k-1}+\phi_{2} \rho_{k-2}+\cdots+\phi_{p} \rho_{k-p}, k>0$

Persamaan di atas merupakan persamaan auto correlation untuk auto regressive (p).

- $\quad$ Auto Correlation Function (ACF) Proses Moving Average (MA)

Untuk mencari persamaan Auto Correlation ,persamaan Moving Average $(q)$ dikalikan dengan $Y_{t-k}$, selanjutnya dicari nilai ekspektasinya sebagai berikut:

$E\left[Y_{t-k} Y_{t}\right]=E\left[\left(\varepsilon_{t}-\theta_{1} \varepsilon_{t-1}-\cdots-\theta_{q} \varepsilon_{t-q}\right)\left(\varepsilon_{t-k}-\theta_{1} \varepsilon_{t-1-k}-\cdots-\theta_{q} \varepsilon_{t-q-k}\right)\right]$

sehingga, secara umum untuk $k=k$ diperoleh persamaan berikut:

$\gamma_{k}=\left(-\theta_{k}+\theta_{1} \theta_{k+1}+\cdots+\theta_{q-k} \theta_{q}\right) \sigma_{\varepsilon}^{2}$

sehingga, 
$\operatorname{MA}(q)$

$\rho_{k}=\frac{\gamma_{k}}{\gamma_{0}}=\frac{\left(-\theta_{k}+\theta_{1} \theta_{k+1}+\cdots+\theta_{q-k} \theta_{q}\right) \sigma_{\varepsilon}^{2}}{\left(1-\theta_{1}^{2}+\cdots+\theta_{q}^{2}\right) \sigma_{\varepsilon}^{2}}, k=1, \ldots, q$

- Partial Auto Correlation Function (PACF) Proses Auto Regressive (AR)

Selain auto correlation function (ACF), partial auto correlation function (PACF) digunakan secara bersama-sama untuk mengidentifikasi model ARMA dari suatu data time series. Partial auto correlation mengukur tingkat keeratan antara $Y_{t}$ dan $Y_{t-k}$, dengan asumsi pengaruh time lag $1,2,3, \ldots$, dan seterusnya sampai $k-1$ dianggap terpisah. Persamaan di bawah ini memperlihatkan bahwa koefisien yang terakhir dari masing-masing persamaan merupakan koefisien auto korelasi parsial. Ini berarti notasi $\hat{\phi}_{1}, \hat{\phi}_{2} \ldots, \hat{\phi}_{m-1}$ dan $\hat{\phi}_{m}$ adalah $m$ buah koefisien auto korelasi parsial yang pertama untuk time series tersebut.

$Y_{t}=\hat{\phi}_{1} Y_{t-1}+\varepsilon_{t}$

$Y_{t}=\hat{\phi}_{1} Y_{t-1}+\cdots+\hat{\phi}_{m-1} Y_{t-m+1}+\hat{\phi}_{m} Y_{t-m} \varepsilon_{t}$

Berdasarkan definisi $E\left(Y_{t} Y_{t-1}\right)=\gamma_{1}, E\left(\hat{\phi}_{1} Y_{t-1} Y_{t-1}\right)=\gamma_{0} \operatorname{dan} E\left(Y_{t-1} \varepsilon_{t}\right)=0$

Karena $\rho_{k}=\frac{\gamma_{k}}{\gamma_{0}}$, operasi di atas dapat diperluas dengan cara mengalikan kedua ruas dengan $Y_{t-k}$, kemudian dihitung nilai ekspektasinya yang merupakan nilai kovariansi. Selanjutnya dengan membagi terhadap $\gamma_{0}$, diperoleh sekumpulan persamaan Yule Walker yang dapat digunakan untuk mencari nilai-nilai $\hat{\phi}_{1}, \hat{\phi}_{2} \ldots, \hat{\phi}_{m-1}$ dan $\hat{\phi}_{m}$. Nilai-nilai ini dapat digunakan untuk menduga nilai-nilai autokorelasi parsial sampai time lag $m$.

Selanjutnya diperoleh:

$\rho_{1}=\phi_{1} \rho_{0}+\phi_{2} \rho_{1}+\cdots+\phi_{p} \rho_{p-1}$

$\rho_{k}=\phi_{1} \rho_{p-1}+\phi_{2} \rho_{p-2}+\cdots+\phi_{p} \rho_{0}$

Dimana $\rho_{1}, \ldots, \rho_{p}$ adalah auto korelasi teoritis sampai lag ke $p$, sedangkan $\phi_{1}, \ldots, \phi_{p}$ adalah $p$ koefisien AR (auto regressive) dari proses AR (p).

- Partial Autocorrelation Function (PACF) Proses Moving Average (MA)

PACF merupakan gabungan dari fungsi menyeluruh secara eksponensial dan atau fungsi sinus meluruh tergantung pada akar-akar dari:

$C(z)=1+b_{1} z+b_{2} z^{2}+\cdots+b_{q} z^{q}$

Proses Penerapan Metode ARIMA

Langkah-langkah dalam penerapan ARIMA yaitu:

1. Identifikasi Model

Model ARIMA hanya dapat digunakan untuk deret waktu yang stasioner. Oleh karenanya hal pertama yang dilakukan adalah menyelidiki apakah data deret waktu sudah stasioner atau belum. Jika data deret waktu belum stasioner, yang harus dilakukan adalah memeriksa pada pembedaan (differencing) berapa data akan stasioner. 
2. Identifikasi ACF dan PACF

Di samping menentukan nilai d, pada tahap ini juga ditentukan berapa jumlah nilai lag residual (q) dan nilai lag dependen (p) yang digunakan dalam model. Alat utama yang digunakan untuk mengidentifikasi q dan $p$ adalah ACF dan PACF (Partial Auto Correlation Function/Koefisien Autokorelasi Parsial), dan correlogram yang menunjukkan plot nilai ACF dan PACF terhadap lag. Koefisien auto korelasi parsial mengukur tingkat keeratan hubungan antara Xt dan Xt-k, sedangkan pengaruh dari time lab 1, 2, 3, ..., k-1 dianggap konstan.

3. Pemilihan Model ARIMA terbaik.

Dari hasil identifikasi stasioneritas dan identifikasi ACF dan PACF maka akan diperoleh beberapa alternatif model ARIMA. Langkah berikutnya adalah melakukan estimasi parameter auto regressive dan moving average yang tercakup dalam model.

4. Diagnostic Checking

Setelah melakukan estimasi dan mendapatkan penduga paramater, agar model sementara dapat digunakan untuk peramalan, perlu dilakukan uji kelayakan terhadap model tersebut.Tahap ini disebut diagnostic checking, di mana pada tahap ini diuji apakah spesifikasi model sudah benar atau belum.

5. Peramalan/Forecasting

Setelah model terbaik diperoleh, selanjutnya peramalan dapat dilakukan. Dalam berbagai kasus, peramalan dengan metode ini lebih dipercaya daripada peramalan yang dilakukan dengan model ekonometri tradisional.

\section{HASIL DAN PEMBAHASAN}

Studi kasus dilakukan terhadap inflasi di Indonesia. Data yang digunakan merupakan data bulanan dari Februari 2011 sampai dengan Februari 2016. Data didapat dari Bank Indonesia. Berikut diberikan grafik dari data aktual inflasi.

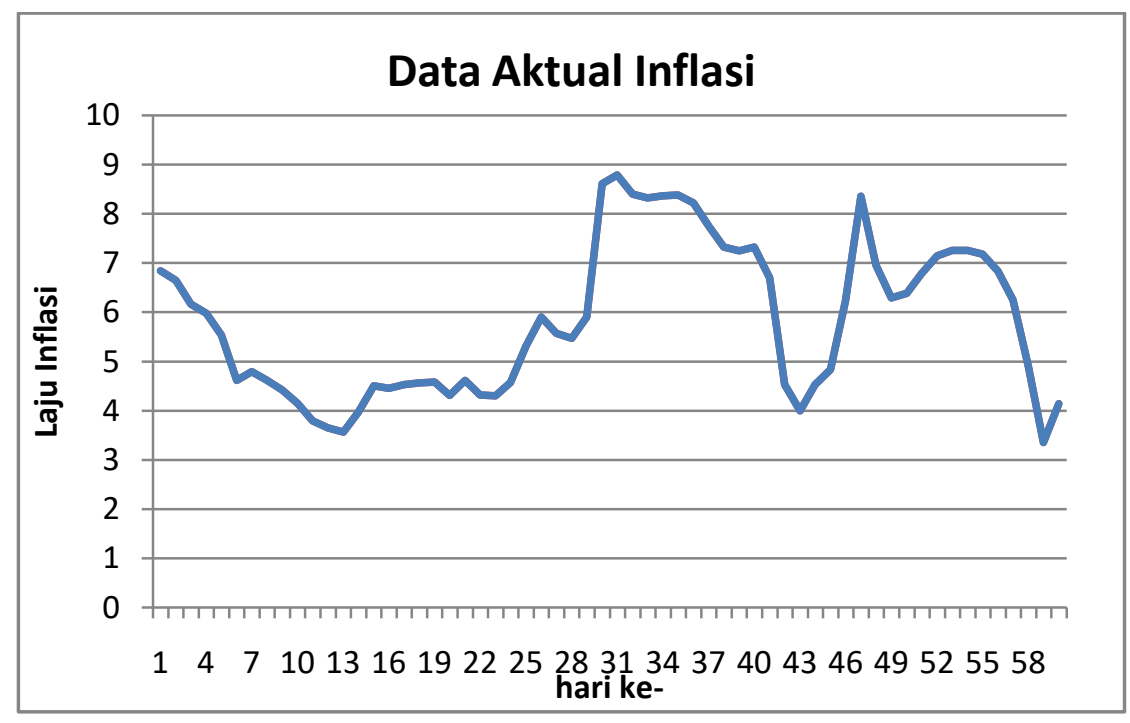

Gambar 1. Data aktual inflasi

Setelah data aktual diperoleh selanjutnya diterapkan proses ARIMA sesuai dengan langkahlangkah pada penerapan proses ARIMA. Pada tahap pertama yaitu Identifikasi Model. Data aktual 
akan diuji stasioneritas dengan menggunakan unit root test. Pada uji stasioneritas pertama data menunjukkan belum stasioner karena nilai kritis pada $\alpha=5 \%$ adalah $-2,912$ yang lebih besar daripada nilai statistik $t$ yang sebesar $-2,551$. Hal ini berarti perlu dilakukan differencing agar data menjadi stasioner. Setelah dilakukan differencing, kemudian dilakukan lagi uni root test untuk melihat stasioneritas.

\begin{tabular}{|c|c|c|}
\hline \multicolumn{3}{|c|}{ Augmented Dickey-Fuller Unit Root Test on D(INFLASI) } \\
\hline \multicolumn{3}{|c|}{$\begin{array}{l}\text { Null Hypothesis: D(INFLASI) has a unit root } \\
\text { Exogenous: Constant } \\
\text { Lag Length: } 0 \text { (Automatic - based on SIC, maxlag=10) }\end{array}$} \\
\hline & t-Statistic & Prob.* \\
\hline Augmented Dickey-Fuller test statistic & -5.558516 & 0.0000 \\
\hline $\begin{array}{lc}\text { Test critical values: } & 1 \% \text { level } \\
& 5 \% \text { level } \\
& 10 \% \text { level }\end{array}$ & $\begin{array}{l}-3.548208 \\
-2.912631 \\
-2.594027\end{array}$ & \\
\hline
\end{tabular}

*MacKinnon (1996) one-sided p-values.

Gambar 2. Uji stasioneritas dengan differencing

Hasil uji unit root test diperoleh bahwa nilai kritis pada $\alpha=5 \%$ adalah-2,912 yang lebih kecil daripada nilai statistik $t$ yang sebesar-5,558. Artinya data sudah stasioner. Setelah data stasioner, tahap selanjutnya yang dilakukan adalah identifikasi ACF dan PACF. Untuk mengidentifikasi ACF dan PACF dapat dilakukan dengan melihat correlelogram berikut:

\begin{tabular}{|c|c|c|c|c|c|c|c|c|}
\hline \multicolumn{9}{|c|}{ Correlogram of D(INFLASI) } \\
\hline \multicolumn{9}{|c|}{$\begin{array}{l}\text { Date: 03/19/16 Time: 06:09 } \\
\text { Sample: } 160 \\
\text { Included observations: } 59\end{array}$} \\
\hline \multicolumn{2}{|c|}{ Autocorrelation } & \multicolumn{2}{|c|}{ Partial Correlation } & \multicolumn{2}{|r|}{$\mathrm{AC}$} & \multirow{2}{*}{$\begin{array}{l}\text { PAC } \\
0.272\end{array}$} & \multirow{2}{*}{$\frac{\text { Q-Stat }}{4.5808}$} & \multirow{2}{*}{ Prob } \\
\hline & $\square$ & 1 & $\square$ & 1 & 0.272 & & & \\
\hline 1 독 & 1 & $\square$ & I & 2 & -0.129 & -0.219 & 5.6346 & 0.060 \\
\hline $1 \mathrm{C}$ & 1 & 1 & 1 & 3 & -0.088 & 0.017 & 6.1283 & 0.106 \\
\hline 15 & 1 & 14 & 1 & 4 & -0.054 & -0.066 & 6.3211 & 0.176 \\
\hline 1 & 1 & 1 & 1 & 5 & -0.006 & 0.016 & 6.3235 & 0.276 \\
\hline & ? & 1 & I & 6 & 0.097 & 0.086 & 6.9560 & 0.325 \\
\hline 1 & 1 & 14 & 1 & 7 & 0.012 & -0.056 & 6.9666 & 0.432 \\
\hline $1 \mathrm{C}$ & 1 & 10 & 1 & 8 & -0.088 & -0.053 & 7.5155 & 0.482 \\
\hline 10 & 1 & 1 & 1 & 9 & -0.032 & 0.015 & 7.5913 & 0.576 \\
\hline 1 & 1 & 1 & 1 & 10 & 0.016 & 0.001 & 7.6091 & 0.667 \\
\hline 15 & 1 & 1 다인 & I & 11 & -0.119 & -0.151 & 8.6682 & 0.652 \\
\hline$\square$ & 1 & $\square$ & 1 & 12 & -0.415 & -0.404 & 21.884 & 0.039 \\
\hline 1 당 & 1 & 1 & ב & 13 & -0.127 & 0.092 & 23.149 & 0.040 \\
\hline 1 & ? 1 & 15 & I & 14 & 0.048 & -0.081 & 23.332 & 0.055 \\
\hline 1 & • & 18 & 1 & 15 & 0.104 & 0.080 & 24.217 & 0.061 \\
\hline 1 & $\square$ & & $\square$ & 16 & 0.279 & 0.255 & 30.742 & 0.015 \\
\hline 1 & $\square$ & 1 & יו & 17 & 0.237 & 0.176 & 35.539 & 0.005 \\
\hline 1 마 & 1 & 1면 & I & 18 & -0.172 & -0.166 & 38.131 & 0.004 \\
\hline 1 등 & 1 & 1 & 1 & 19 & -0.133 & 0.018 & 39.720 & 0.004 \\
\hline
\end{tabular}

Gambar 3. Correlelogram

Dari Gambar 3, data pada kolom PACF (Partial Correlation) digunakan untuk menentukan ordo maksimal AR(p). Dari PACF (Partial Correlation) tersebut ternyata periode time lag pertama keluar dari garis batas (mulai menurun nilainya mendekati nol setelah lag pertama). Sedangkan pada kolom ACF (Auto Correlation) digunakan untuk menentukan MA(q). Dari ACF (Auto Correlation) ternyata 
periode time lag pertama juga yang keluar dari garis batas (mulai menurun nilainya mendekati nol setelah lag pertama). Artinya ARIMA yang mungkin adalah ARIMA(1,1,1).

Tahap ketiga adalah pemilihan Model ARIMA terbaik. Oleh karena ARIMA yang mungkin dari data inflasi adalah ARIMA $(1,1,1)$, maka ARIMA $(1,1,1)$ langsung dipilih sebagai model ARIMA yang terbaik.

\begin{tabular}{|c|c|c|c|c|}
\hline \multicolumn{5}{|c|}{$\begin{array}{l}\text { Dependent Variable: D(INFLASI) } \\
\text { Method: Least Squares } \\
\text { Date: } 03 / 20 / 16 \text { Time: } 14: 48 \\
\text { Sample (adjusted): } 360 \\
\text { Included observations: } 58 \text { after adjustments } \\
\text { Convergence achieved after } 55 \text { iterations } \\
\text { MA Backcast: OFF (Roots of MA process too large) }\end{array}$} \\
\hline Variable & Coefficient & Std. Error & t-Statistic & Prob. \\
\hline $\begin{array}{l}\mathrm{AR}(1) \\
\mathrm{MA}(1)\end{array}$ & $\begin{array}{r}-0.383781 \\
1.147715\end{array}$ & $\begin{array}{l}0.110464 \\
0.026644\end{array}$ & $\begin{array}{r}-3.474269 \\
43.07597\end{array}$ & $\begin{array}{l}0.0010 \\
0.0000\end{array}$ \\
\hline $\begin{array}{l}\text { R-squared } \\
\text { Adjusted R-squared } \\
\text { S.E. of regression } \\
\text { Sum squared resid } \\
\text { Log likelihood } \\
\text { Durbin-Watson stat }\end{array}$ & $\begin{array}{r}0.270034 \\
0.256999 \\
0.643952 \\
23.22174 \\
-55.75316 \\
2.337005\end{array}$ & \multicolumn{2}{|c|}{$\begin{array}{l}\text { Mean dependent var } \\
\text { S.D. dependent var } \\
\text { Akaike info criterion } \\
\text { Schwarz criterion } \\
\text { Hannan-Quinn criter. }\end{array}$} & $\begin{array}{r}-0.043276 \\
0.747065 \\
1.991488 \\
2.062538 \\
2.019164\end{array}$ \\
\hline $\begin{array}{l}\text { Inverted AR Roots } \\
\text { Inverted MA Roots }\end{array}$ & $\begin{array}{c}-.38 \\
-1.15 \\
\text { Estimated MA }\end{array}$ & process is no & hinvertible & \\
\hline
\end{tabular}

Gambar 4. Estimasi ARIMA $(1,1,1)$

Setelah model terbaik telah dipilih, tahap selanjutnya adalah melakukan Diagnostic Checking. Diagnostic Checking yang dilakukan yaitu uji normalitas, uiji heteroskedastisitas dan uji autokorelasi.

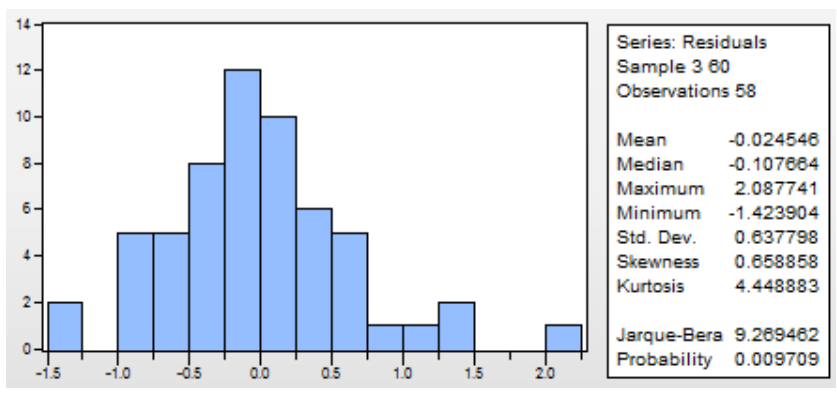

Gambar 5. Uji normalitas

Pada Gambar 5 terlihat bahwa nilai probabilitas adalah 0,009. Hal ini berarti nilai probabilitas lebih kecil dari nilai $\alpha=5 \%$, maka data tidak berdistribusi normal.

Heteroskedasticity Test: White

\begin{tabular}{llll}
\hline \hline F-statistic & 3.254142 & Prob. F(1,56) & 0.0766 \\
Obs*R-squared & 3.185267 & Prob. Chi-Square(1) & 0.0743 \\
Scaled explained SS & 8.400086 & Prob. Chi-Square(1) & 0.0038 \\
\hline \hline
\end{tabular}

Gambar 6. Uji Heteroskedatisitas 
Selanjutnya adalah uji heteroskedatisitas. Pada Gambar 6 terlihat bahwa nilai probabilitas sebesar 0,0038 , lebih kecil dari nilai $\alpha=5 \%$ sehingga dapat disimpulkan bahwa data tersebut bersifat heteroskedastis. Terakhir adalah uji autokorelasi sebagai berikut:

\begin{tabular}{lrll}
\multicolumn{4}{l}{ Breusch-Godfrey Serial Correlation LM Test: } \\
\hline \hline F-statistic & 1.742339 & Prob. F(2,55) & 0.1846 \\
Obs*R-squared & 3.380984 & Prob. Chi-Square(2) & 0.1844 \\
\hline \hline
\end{tabular}

Gambar 7. Uji Autokorelasi

Pada Gambar 7 terlihat bahwa nilai probabilitias sebesar 0,1844 lebih besar dari nilai $\alpha=5 \%$. Hal ini mengindikasikan bahwa data tidak mengandung masalah autokorelasi. Setelah tahap diagnostic checking dilakukan, maka tahap terakhir yang dilakukan adalah peramalan.

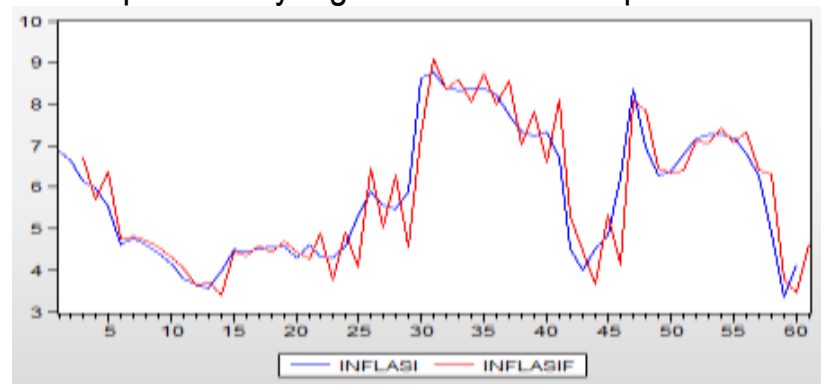

Gambar 8. Grafik Data Aktual vs Peramalan

Pada Gambar 8 merupakan grafik perbandingan antara data aktual dari inflasi dan hasil peramalan. Adapun hasil peramalan dari model ARIMA $(1,1,1)$ menunjukkan bahwa data pergerakkan inflasi untuk satu periode ke depan adalah 0,6285\% atau 6,285.

Selanjutnya disajikan grafik perbandingan antara data aktual, $\operatorname{ARIMA}(1,1,1), A R(1)$ dan MA(1) seperti pada Gambar 9.

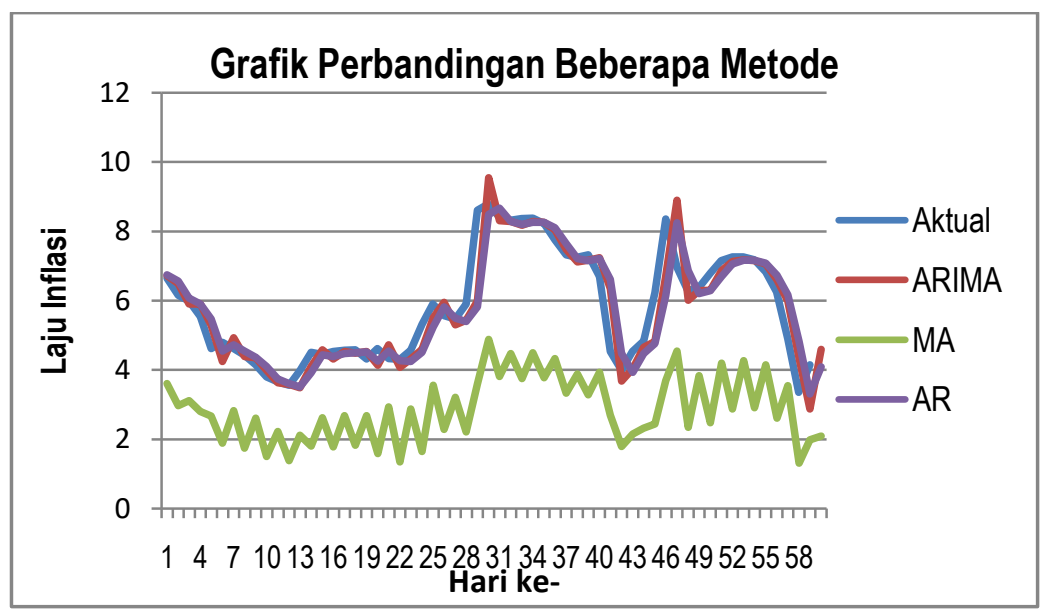

Gambar 9. Grafik perbandingan beberapa metode 
Pada Gambar 9 terlihat bahwa hanya metode ARIMA dan AR yang mampu mengikuti data aktual, sedangkan metode MA tidak mampu mengikuti data aktual laju inflasi. Saat metode-metode tersebut diestimasi maka nilai Sum Squared Error (SSE) memberikan hasil yang berbeda-beda. Untuk metode ARIMA SSEnya adalah 23,22, AR adalah 31,51 dan MA adalah 577,36. Hal ini berarti metode yang terbaik untuk meramal laju inflasi adalah metode ARIMA $(1,1,1)$. Artinya, salah satu metode peramalan yang baik digunakan untuk meramalkan laju inflasi adalah menggunakan ARIMA. Hal ini terlihat dari hasil estimasi yang diberikan. Hal ini juga sesuai dengan hasil penelitian terdahulu (Tripena, A, 2011) yang menyatakan bahwa metode ARIMA Box-Jenkins adalah metode deret waktu linear terbaik untuk meramalkan indeks harga konsumen dan inflasi.

\section{SIMPULAN}

Berdasarkan hasil penelitian mengenai peramalan dengan menggunakan Auto Regressive Integrated Moving Average atau ARIMA untuk data laju inflasi memberikan hasil peramalan sebesar $0,6285 \%$ atau 6,285 . Berdasarkan grafik data terlihat bahwa hasil peramalan menggunakan metode ARIMA mampu mengikuti pergerakkan data aktual dari laju inflasi. Selain itu, berdasarkan hasil estimasi diperoleh nilai Sum Squared Error sebesar 23,22. Selanjutnya berdasarkan hasil diagnostic checking yakni dengan uji normalitas diperoleh data tidak berdistribusi normal namun untuk uji heteroskedastik memberikan hasil bahwa data bersifat heteroskedastis, dan uji autokorelasi menunjukkan bahwa data tidak mengandung masalah autokorelasi.

\section{REFERENSI}

Box, G. E. P., \& G. M. Jenkins. (1976). Time series analysis forecasting and control. Holden-Day. Sa Fransisco.

Makridakis, S., Wheelwright, S.C., \& McGee, V.E. (2002). Metode aplikasi dan peramalan. Jakarta. Binarupa Aksara Publisher.

Pimpi, La. (2013). Penerapan metode ARIMA dalam meramalkan indeks harga konsumen (IHK) Indonesia Tahun 2013. Jurnal paradigma, Vol. 17; Hal. 35.

Ruslan, R., Agus Salim Harahap., \& Pasukat Sembiring. (2013). Peramalan nilai ekspor di propinsi Sumatera Utara dengan metode ARIMA Box Jenkins. Jurnal saintia matematika, Vol. 1; Hal 579.

Saluza, I. (2015). Aplikasi metode jaringan syaraf tiruan backpropagation dalam meramal tingkat inflasi di Indonesia. Jurnal gradien, Vol. 11; hal.1075. Universitas Bengkulu.

Slutsky, E.E. (1937). The summation of random causes as the source of clclical processes. Econometrica, 5; 46-105.

Stehpani, C. A, Agus Suharsono, \& Suhartono. (2015). Peramalan inflasi nasional berdasarkan faktor ekonomi makro menggunakan pendekatan time series klasik dan ANFIS". Jurnal sains dan seni, Vol. 4; hal. D-67.

Wold. H. (1938). A study in the, analysis of stationary time series, $1^{\text {st }}$ ed. Uppsala: Almqvist and Wiksells.

Wulandari, N., Setiawan., \& Imam Safawi Ahmad. (2016). Peramalan inflasi kota surabaya dengan pendekatan ARIMA, variasi kalender, dan intervensi. Jurnal sains dan seni, Vol. 5; Hal. D-90.

Yule, G. U. (1927). On a method of investigating periodicities in disturbed series, with special reference to wolfer's sunspot numbers. Philosopical transactions of the royal society A: Mathematical, phisycal, and engineering science, 226(636-646); 226-267. 